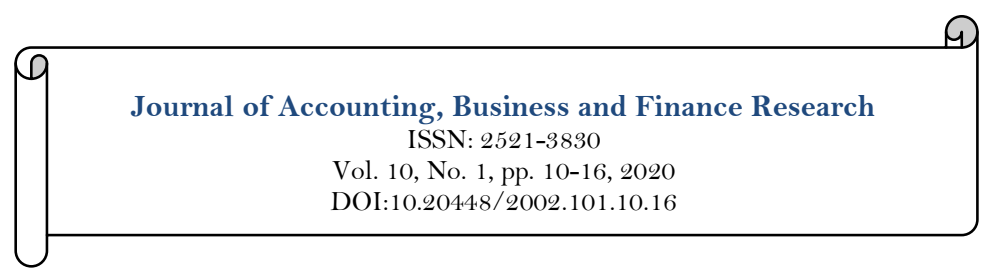

\title{
Economic Policy Uncertainty and Firm Performance in the Czech Republic
}

\section{Ivanka Nestoroska}

Masaryk University, Faculty of Economics and Administration, Czech Republic. Email:Ivankanestecon@gmail.com

\begin{tabular}{|c|c|}
\hline Abstract & \\
\hline $\begin{array}{l}\text { The business environment undergoes a number of changes due to the } \\
\text { decisions made by the government and politicians of a particular country } \\
\text { and this impacts the performance of the firms that operate in that business } \\
\text { environment. In other words, the uncertainty in decisions of the government } \\
\text { and politicians and the policies made by them impact the financial decisions } \\
\text { of the firms. In this regard, the current study has been conducted to discover } \\
\text { and examine the affect casted by EPU on the performance of the company } \\
\text { within Czech Republic. Financial data has been collected from the public } \\
\text { non-financial companies of Czech Republic. The data has been collected for } \\
\text { the time of } 29 \text { years. The data gathered against the most reliable databases } \\
\text { such as World Bank Development Indicators and Global Economy about the } \\
\text { required variables. The GMM estimation technique was applied on the } \\
\text { collected data and the results were obtained. The results obtained indicate } \\
\text { that unreliability has significant as well as bad effect on the performance of } \\
\text { the company and in opposite way; the interest rate has significant along with } \\
\text { positive impact on firm's performance. But the inflation rate's impact is } \\
\text { notable and rare only in case of net profit margin proxy of the performance } \\
\text { of the company. Practical implication of the knowledge is for non-financial } \\
\text { firms of Czech Republic and it might assist them in designing policies and } \\
\text { regulations regarding the precautionary measures which can be taken in case } \\
\text { of EPU so that the financial performance of the firms is not disturbed. }\end{array}$ & $\begin{array}{l}\text { Keywords: } \\
\text { Economic policy uncertainty } \\
\text { Firm performance } \\
\text { Czech republic } \\
\text { Return on assets } \\
\text { Net profit margin. } \\
\text { Licensed: } \\
\text { This work is licensed under a } \\
\text { Creative Commons Attribution } 4.0 \\
\text { License. } \\
\text { Publisher: } \\
\text { Scientific Publishing Institute } \\
\text { Received: } 4 \text { May } 2020 \\
\text { Revised: } 12 \text { June } 2020 \\
\text { Accepted: } 26 \text { June } 2020 \\
\text { Published: 28 July } 2020\end{array}$ \\
\hline
\end{tabular}

Funding: This study received no specific financial support.

Competing Interests: The author declares that there are no conflicts of interests regarding the publication of this paper.

\section{Introduction}

The unreliability own a cross-cutting effect on all sections of moneymaking as it directly impacts the businesses, household and financial market, and this economic policy-based uncertainty makes a huge economic risk of the state's prosperity. This risky situation leads to detain the money and expenditure till the unreliability has been settled (Baker, Bloom, \& Davis, 2016; Ghosh, 2019; Perić \& Sorić, 2018). This paper is majorly based on considering this economic policy uncertainty factor as a threatening situation in front of the Czech Republic to stabilize its economy in a challenging situation. Well, its yearly-wise inflation rate is shown in the following table which depicts that with time, its inflation rate is continuously increasing which shows a threatening situation in front of its management to maintain its firm performance within a state (Czech Republic Inflation Rate, 2020). After this inflation rate description, it becomes clear that the majority of its firm's performance is in alarming situation. Well, its gross domestic product (GDP) growth is continuously suffering since the last few years. Also, in the half-year performance of the current year (2020), its growth is negatively increased by $-3.3 \%$ which means, there is an occurrence of economic policies uncertainty towards its 
national company's growth (Jindřichovská, Ugurlu, \& Thalassinos, 2020). Its graphical outcomes are shown in the following Figure 1.

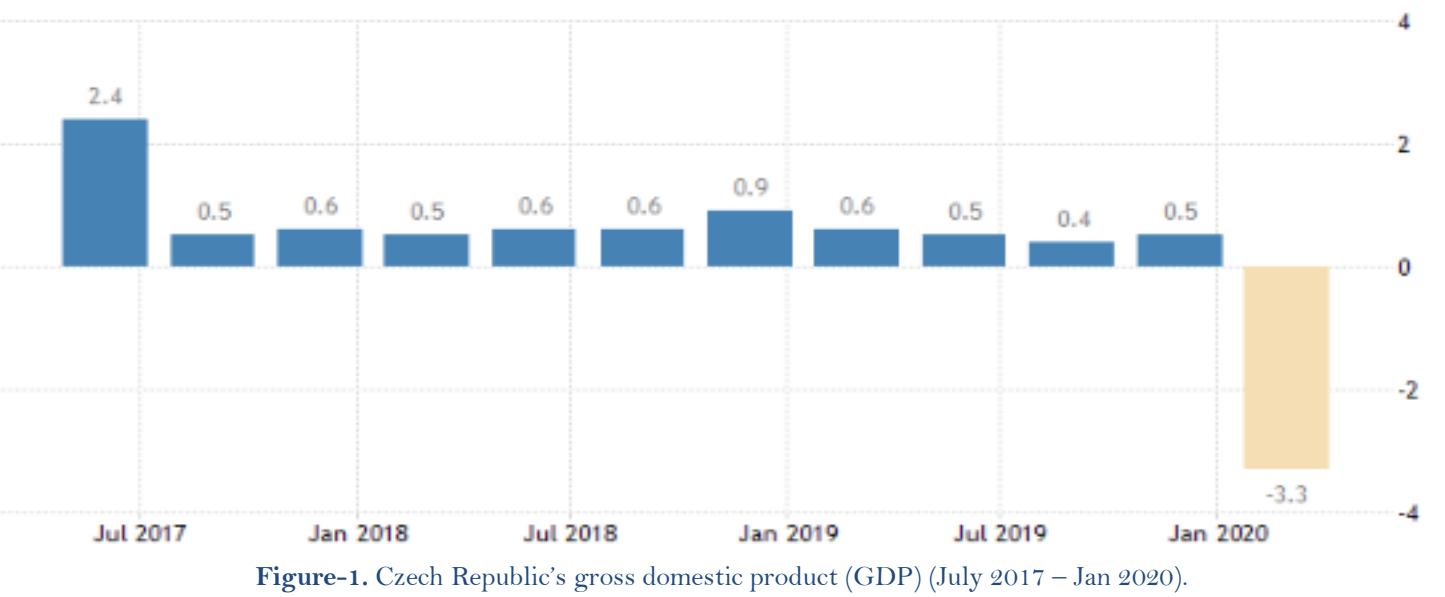

In this paper, a problem statement is majorly based on examining the impact of economic policy uncertainty on the return on asset and net profit margin based economic performance of a firm, by considering the case study of the Czech Republic. This argument will help to understand how the interest rate and inflation oriented state's economic policy may cause a major impact on the sustainable growth of an organization.

A prospective theory is such economic theory which was developed by Amos Tversky and Deniel Kahaneman in 1979 by challenging the expected utility theory. This is a founding theory of behavioral finance and behavioral economics which based on discussing how a person accesses the gain and loss asymmetrically. In the case of economic policy uncertainty, this theoretical approach plays a significant role in generating the behavioral approach to stabilize that economic risk factor. This is a helpful approach to understand the asymmetric form of risk aversion by considering the economic uncertainty in different perspectives. This perspective theory is already utilized by previous scholars to justify their tested variables like in the Industrial Marketing Management Journal, Cortez and Johnston (2017) considered the prospective theory-based analysis on evaluating the future of the B2B marketing theory. They focused on developing a bridge between the academics and practitioners and in the end, developed six major areas of inquiry named as data analytics, innovation, harnessing technology, customer journey and relationship, revenue growth, finance/ marketing interface and the industry context (Cortez \& Johnston, 2017). Also, Jurgen Brauer and Charles Anderton considered this theoretical approach in conflict economics and also considered the interrelation between economics and the conflicts (Brauer \& Anderton, 2020). In evaluating the destruction of the capital in an economy, a potential hypothesis-based recovery within the literature of Marxian crisis was developed by Marcus Synnott, who stated that Marxian academic inquiry is directly anxious with the investor build-up which inherit crisis and contradiction without focusing the methods to escape from it Synnott (2019).

In the emerging bazaar review based informative journal, a research was conducted by Demir and Ersan (2017) where they stated that firms are preferred to take more money when the unreliability level becomes enlarges. According to them, the ten points produce in EPU cause a $0.8 \%$ increase in the cash holding ratio. In the end, they concluded that universal EPU has an effective effect on the belongings of combined cash within a state (Demir \& Ersan, 2017). Well in 2020, the researchers examine the effect of EPU on the financial stability of 23 states where they concluded that this EPU factor has a gloomy and the numerically effective impact on the monetary strength of a state. While the effect is majorly dependent on the predictable of the monetary structure (Phan, Iyke, Sharma, \& Affandi, 2020). Also, in the publication of international monetary market institution and cash, research was developed by Dinh Hoang Bach Phan and others by considering the effect of EPU on the stock return prediction. According to these researchers, the EPU effectively predicts the stock return based on the country and sector-wise information because such prediction helps to make a proper assumption regarding the upcoming uncertainty in the economic policies. Their outcomes depict that positive and negative EPU directly predicts the stock excess returns within a state (Phan et al., 2020). According to these scholars, there is a time-series variation impact on the return of assets within this developing state because this EPU significantly predicts the gloomy future stock bazaar returns at the many views (Chen, Jiang, \& Tong, 2017). Their outcomes show that in the behavioral asset pricing model, the high uncertainty directly generates the speculative mispricing and amplifies the behavioral biases under the short-sales constraint. According to results, such uncertainty enhanced the cost of capital of a firm that directly translates into the lower innovation $(\mathrm{Xu}, 2020)$. Also, the other scholars stated that oil call-side shock has a effective impact on the oil and gas firms' returns, while the shocks to policy unreliability negatively impact on the 
return (Kang, de Gracia, \& Ratti, 2017). Thus, after evaluating the previous research on EPU and return on money-based variables, the following hypothesis has been suggested;

Handley and Limao (2015) stated the policy uncertainty of trade and investment in their dynamic model. According to them, the export investment of firms is lower under the trade policy uncertainty and the credible at the preferential trade agreements that increased the trade (Handley \& Limao, 2015). After this in 2019, research was specifically considered on evaluating the relationship between the EPU on the stock risk feature by using a stochastic discount model (Azam, Nawaz, \& Riaz, 2019). According to these researchers, the policy uncertainty can easily boost risk through discounting factors, enterprise cash flow and correlation coefficient. They stated that the effect is still significant after the controlling the corporate heterogeneity, traditional risk factors and the external environmental factors, so it becomes clear that the magnitude of the policy uncertainty's effect on the stock risk is much higher when the economy becomes weaker and the policy environment is more unstable (Iqbal et al., 2020). In the recent year 2020, the latest research is conducted by Surendranath Jory and others on exploring the impact of EPU on the firm value and the cooperate trade credit. According to these scholars, the EPU exerts a negative impact on the trade credits' length. They stated that the indirect association between the trade credit and EPU robust the alternative specialization, while the firm is adjusted trade credit during the EPU that are highly associated with the high market-to-book ratios (Jory, Khieu, Ngo, \& Phan, 2020). In the same year, relevant research is conducted by Mikhail Stolbov and Maria Shchepeleva in their international business and finance journal where they examine the association between EPU, systematic risk and the firm bankruptcies. According to their coincident outcomes, the systematic risk causes a firm to exist in Spain, while the Netherlan and the UK bankruptcies are triggered by using the EPU. Overall their outcomes show that the overall profit margin based economic activities of a firm are majorly dependent on the EPU factor that easily predict its future.

The research objectives of study are;

- To critically examine the effect of economic policy uncertainty (EPU) on the return on asset-based firm performance within the Czech Republic.

- To critically examine the effect of economic policy uncertainty (EPU) on the net profit margin based firm performance within the Czech Republic.

- To critically evaluate the effect of rate absorption and inflation rate on the company's economic performance.

This research is an informative approach which majorly covers the gap of the previous scholars who worked on considering the effect of EPU on the developing state's and the US firms (Chen, Lee, \& Zeng, 2019; Iqbal, Gan, \& Nadeem, 2020). In addition to this, there was also worked on impact of the flows of universal trade on the EPU, its impact on export and spillover the retail of stock due to this uncertainty factor (Jia, Huang, Xu, \& Sun, 2020; Skrinjarić \& Orlović, 2020; Tam, 2018). But nobody majorly worked on the case study of the Czech Republic and its firm's performance in the uncertain situation. This factor is specifically considered in this study which will give a new direction to the researchers to focus on the European states in the economic uncertainty phase.This paper is an informative approach for the business community of the Czech Republic to recognize the significance of EPU on their overall firms' performance within this developed state. Also, this paper will help the state's government and the policymakers to develop such economic policies that fulfil the firms' desires of profit margin. Also, the related field economist and researchers can utilize this valid information in their research discussion portion. After considering this introductory section, the research methodology based second section will be based on discussing the research method, its data collection, and the GMM estimation test for the evaluation mechanism. Section third, results and analysis will be based on interpreting all the statistical outcomes of the analysis. Last, but not the least, the discussion and conclusion portion will focus on considering the statistical outcomes with the real market situation. In addition, the implications for future and weakness of this paper for the upcoming researches will be made.

\section{Methodology}

\subsection{Data Collection and Variables}

The current study has the basic motive to explore and look into the impact casted by economic policy uncertainty EPU on the firm performance in Czech Republic. As far as EPU is concerned, it is not a continuous process and this is the reason if some uncertain thing happens, it might lose its intensity with the period of time and its impact on the firm performance might also be decreased. It has been known that the data regarding EPU is collected on monthly and thus the impact casted by it on the firm performance can be measured accurately. On the other hand, the data about the firm's performance that is measured on the basis of financial aspects of that particular firm is collected quarterly, semiannually and annually basis. However, in the current study, the financial data has been collected about two aspects i.e. Return on Assets along with Net Profit Margin and this collection have been made on quarterly basis. The financial data has been collected from the public non financial companies of Czech Republic. The data has been collected for 29 years. The data has been composed from the most reliable databases such as World Bank Development Indicators and Global Economy about the required variables. It must be noted here that in addition to the dependent variables i.e. return on assets along with net profit margin and independent variable, EPU, the researcher has also 
considered two control variables i.e. inflation rate and interest rate in the current study. The econometric models that can be used in the current study are as follows;

$$
\begin{aligned}
& R O A_{i t}=\alpha+\beta_{1} E P U_{i t}+\beta_{2} I N T_{i t}+\beta_{3} I N F_{i t}+\varepsilon_{i t} \\
& N P M_{i t}=\alpha+\beta_{1} E P U_{i t}+\beta_{2} I N T_{i t}+\beta_{3} I N F_{i t}+\varepsilon_{i t}
\end{aligned}
$$

In these equations, $\alpha$ is a constant value, i represents the company from which data has been collected, $t$ is the time of the year, $\beta$ indicates the coefficient of the variables, ROA means the return on assets measured and NPM represents net profit margin both of which are ratios and are measured as percentage. Both of these terms indicate the firm performance or in other words, are the proxies of firm performance. Moreover, EPU represents economic policy uncertainty which is measured by using its proxy i.e. BBD (Baker, Bloom, Davis) index, INT shows interest rate, INF indicates inflation rate and lastly $\varepsilon_{i t}$ is the error term. In this way, the researcher has collected the required data for the research and analysis purpose.

\subsection{Unit Root Test}

In the estimation procedure of research, the researcher has firstly applied the unit root test so that the stationary properties and order of integration of the variables can be identified prior to moving to the further techniques and tools. In the current study the researcher has used the LLC test for the aforementioned purpose. The null hypothesis is that there is unit root in the collected data and it is non stationary while the alternate hypothesis means there is no presence of unit root and the collected data is stationary. This leads to the outcome that whether the variables of the study are having first order integration, zero order integration or the mixture of both of them Levin, Lin, and Chu (2002). The following equation might be considered in this regard;

$$
\Delta y_{i, t}=a_{i}+\rho y_{i, t}-1+\sum_{J=1}^{p i} a_{J} \Delta y_{i, t-J}+\varepsilon_{i, t}
$$

The researcher has used a number of diagnostics tests in order to gain the basic information about different properties of the collected data. These tests include "autocorrelation", "heteroscedasticity" and "cross sectional dependence" tests along with "multicollinearity" test. The application of these tests is necessary because it provides information about the correlation, heteroscedasticity, cross section dependence and multiciollinearity of the data. In the absence of these tests, the results obtained might be ambiguous (Pesaran, 2004).

\subsection{GMM Estimation}

The priority of the researcher in the current study was to apply the ordinary least square test and fixed effects but the diagnostics tests indicated that the variables of the study are heteroscedastic and are having autocorrelation with each other. In addition, the cross sectional dependence has also been found among the variables. So the researcher cannot use OLS and fixed effect techniques for the estimation of the collected data. This leads to the application of GMM estimation technique which has the capability to resolve the aforementioned issues. If these issues are ignored the there is high degree of possibility that the results obtained might be biased while on the other hand, GMM estimation is a better approach to cater these issues (Arellano \& Bover, 1995; Blundell \& Bond, 1998). The impacts casted by the independent variables on the dependent variable can be measured and explored through the use of this particular technique. The following equation might be considered in context of the GMM estimation technique.

$$
\vartheta_{i t}=\alpha_{i}+\gamma \vartheta_{i, t-1}+\sum_{p=1}^{p} \beta_{p} Z^{p} i t+\sum_{q=1}^{q} \beta_{q} Z^{q} i t+\sum_{r=1}^{r} \beta_{r} Z^{r} i t+\epsilon_{i t}
$$

\section{Results Analysis}

\subsection{Unit Root Test}

In the estimation procedure of the current study, the researcher, on the first hand, applied the Levin Lin Chu unit root test so that the stationary and stochastic qualities of the variables along with their order of integration can be identified effectively. The detailed results of this test have been reported by the researcher in the Table 2 , in which the unit root values of all the variables have been given along with the significance of rejection in the form of stars $\left(^{*}\right)$. As far as the level side is considered, it is clear that only two variables i.e. EPU and interest rate have shown rejection of the null hypothesis of unit root. This leads to the result that in this side i.e. the collected data has unit root and shows non stationary behavior. On the other hand, when this issue was resolved by first differencing the variables of the study, it came out that all the variables now have rejected the null hypothesis having unit root. This leads to the result that the collected data has no unit root and shows stationary behavior in the first difference side. In addition, it can also be deduced from these results that the order of integration associated with the variables are either zero of first order integration, making the collected data eligible to move forward for the other estimation techniques. 
Table-2. LLC unit root.

\begin{tabular}{c|c|c|c|c|c}
\multicolumn{7}{c}{ Table-2. LLC unit root. } \\
\hline Constructs & ROA & NPM & EPU & INT & INF \\
\hline At Level & -0.632 & -3.764 & $-4.432^{*}$ & $-6.762^{*}$ & -3.623 \\
\hline First difference & $-6.726^{* * *}$ & $-9.411^{* *}$ & $-7.812^{* * *}$ & $-9.711^{* * *}$ & $-7.934^{* *}$ \\
\hline
\end{tabular}

\subsection{Diagnostic Checks}

In continuation of the estimation procedure, the researcher has employed various diagnostic checks on the collected data after the application of unit root test. The purpose to use these tests is to explore the basic properties of the collected data to make sure if the data is eligible to be applied further tests of not. The detailed results of all these tests have been reported by the researcher in the Table 3 . The heteroscedasticity test results indicate that the collected data has been found to possess a certain amount of heteroscedasticity. In the exact similar way, the autocorrelation test results clearly indicate that the variables of the study possess some amount of autocorrelation among them. Similarly, the results of cross section dependence test suggest that there is significant dependence amid the variables. However, the results of the multicollinearity test have shown no evidence of the variables having multicollinearity among them. After these diagnostic tests, the next step was to use the correlation matrix in order to find out whether there is any correlation between the variables or not. The correlation matrix has been presented in a separate Table 4. According to the table, the variables are found to have no correlation among them at all. Moreover, the general or direct relationships can also be estimated through the same matrix.

Table-3. Diagnostic checks.

\begin{tabular}{|c|c|c|c|}
\hline Heteroskedasticity & Autocorrelation & Cross-section dependence & Multicollinearity \\
\hline $\begin{array}{l}\text { Modified wald } \\
\text { Breusch-Pagan/Cook-Weisberg }\end{array}$ & Wooldridge & Pesaran & VIF \\
\hline $\begin{array}{l}\chi^{2} \text {-value: } 12.30^{* *} \\
\chi^{2} \text {-value: } 9.54^{* *}\end{array}$ & F-statistic: $8.60^{*}$ & Test statistic: $7.941^{*} *$ & Mean VIF: 1.42 \\
\hline
\end{tabular}

\begin{tabular}{c|c|c|c|c|c}
\multicolumn{7}{c}{ Table-4. Correlation matrix. } \\
\hline Variables & ROA & NPM & EPU & INT & INF \\
\hline ROA & 1 & & & & \\
\hline NPM & .632 & 1 & & & \\
\hline EPU & .926 & .284 & 1 & & \\
\hline INT & .371 & .482 & .922 & 1 & \\
\hline INF & .116 & .831 & .734 & .734 & 1 \\
\hline
\end{tabular}

\subsection{GMM Estimation}

Finally the researcher has applied the GMM estimation approach to the data. The outcomes of the GMM estimation for the two dependent variables, ROA and NPM have been presented separately in the Tables 5 and 6. According to Table 5, it is quite clear that EPU has significant and negative shock on the return on assets of the firm. It can be said that with the increase in EPU, the return on assets might fall by $37.6 \%$ in the non-financial firms. In the opposite way, the impact of inflation rate has found not important impact on the ROA while the interest rate has noteworthy along with positive impact on the return on assets. In other words, with the increase in one percent of interest rate, the return on assets will be enhanced by $16.3 \%$.

On the other hand, in case of net profit margin, the Table 6 shows that EPU has significant and unconstructive impact on the ROA of the firm. In other words, it can be said that with the increase in EPU, the return on assets might fall by $17.3 \%$ in the non financial firms. In the same way, the impact of inflation rate and the interest rate is significant and positive on the return on assets. In other words, with the increase in one percent of interest and inflation rate, the return on assets will be enhanced by $27.2 \%$ and $28.4 \%$ respectively.

Table-5. Results from GMM estimation (ROA).

\begin{tabular}{l|l}
\hline Dependent Variable $=$ ROA & Sys-GMM estimation \\
\hline EPU & $-0.376^{* * *}(0.001)$ \\
\hline INF & $0.185(0.923)$ \\
\hline INT & $0.163^{* *}(0.042)$ \\
\hline Constant & $0.642^{* *}(0.016)$ \\
\hline$R^{2}$ & - \\
\hline Arellano-Bond test for $A R(1)(\operatorname{Pr} W \approx)$ & 0.753 \\
\hline Arellano-Bond test for AR $(2)(\operatorname{Pr} W z)$ & 0.452 \\
\hline Hansen test of overid restrictions & 1.529 \\
\hline
\end{tabular}


Table-6. Results from GMM estimation (NPM)

\begin{tabular}{l|l}
\hline Dependent Variable = NPM & Sys-GMM estimation \\
\hline EPU & $-0.173^{* *}(0.033)$ \\
\hline INF & $0.284^{* *}(0.047)$ \\
\hline INT & $0.272^{* *}(0.039)$ \\
\hline Constant & $0.478^{* *}(0.023)$ \\
\hline$R^{2}$ & - \\
\hline Arellano-Bond test for $A R(1)(\operatorname{Pr} W z)$ & 0.732 \\
\hline Arellano-Bond test for AR $(2)(\operatorname{Pr} W z)$ & 0.512 \\
\hline Hansen test of overid restrictions & 1.882 \\
\hline
\end{tabular}

\section{Discussion and Conclusion}

\subsection{Discussion}

The motive behind the current study was to search the impact casted by economic uncertainty policy on the firm performance of different non-financial companies of Czech Republic. For this purpose, the firm performance has been taken by its two proxies i.e. ROA and NPM. On the other hand, the proxy of EPU was taken as the BBD index. In addition, two control variables were also considered in the study i.e. inflation rate and interest rate. The GMM estimation technique was applied on the collected data and the results were obtained. The results have indicated that EPU has major and negative impact on the return on assets as well as net profit margin of non-financial companies of Czech Republic. In other words, it can be stated that the performance of the firm decreases when uncertainty increases in the economic policies. This might be because of the reason that the investments made by the firms are decreased and the performance of the firms is associated with the profit and loss of the investments. When the uncertainty increases, the risk associated with these investments also increases which ultimately reduces the firm performance. The result obtained in this regard is as same as it was expected. The similar results have been presented by the researchers who had conducted the similar studies in the past (Arbatli, Davis, Ito, \& Miake, 2017; Zeng, Zhong, \& He, 2020). As far as the inflation rate is concerned, its impact has been found as significant and positive on the net profit margin but the impact is insignificant for return on assets. This might be because of the reason that the net profit margin is increased with the increase in prices of different commodities and thus the inflation rate increases the net profit margin. This result is in concordance with the literature from the past (Balcilar, Gupta, \& Segnon, 2016; Hu, Kutan, \& Sun, 2018). The last result of the study is that the interest rate increases in return on assets as well as net profit margin significantly in the non-financial firms of Czech Republic. All these results are in consistency with the similar studies from the past (Huang, Chen, \& Lee, 2019; Tam, 2018). In this way, all the results have been discussed and to put them in a nutshell, it can be suggested that EPU has significant and depressing impact on the firm's performance and in the opposite way; the interest rate has significant along with positive impact on firm performance. But the impact of inflation rate is significant and positive only in case of net profit margin proxy of firm performance.

\subsection{Conclusion}

After the application of GMM estimation on the collected panel data from different non financial firms of Czech Republic, the researcher has obtained the required results. These results provide info that EPU has momentous plus negative impact on the firm performance and in the opposite way; the interest rate has major as well as positive impact on firm's performance. But the impact of inflation rate is significant and positive only in case of net profit margin proxy of firm performance. Based upon these results, it can be concluded that the non-financial firms of Czech Republic must design policies and regulations regarding the precautionary measures which can be taken in case of EPU so that the financial performance of the firms is not disturbed. The same is applicable for all the stakeholders that are associated with the firm in one way or the other.

\subsection{Implications and Limitations}

The practical implication of the study is for the non-financial firms of Czech Republic and it might assist them in designing policies and regulations regarding the precautionary measures which can be taken in case of EPU so that the financial performance of the firms is not disturbed. The same is applicable for all the stakeholders that are associated with the firm in one way or the other. This shows the wide scope of the implications of the study. In addition to this, the researcher might also find implications in the current study as they can get literature and information about the impact of EPU on the firm's performance in context of Czech Republic and use it in their researches. In addition, they might also improve the study by following some recommendations such as to increase the sample size, application of other panel data tests as well, selection of some other country or region for study purpose.

\section{References}

Arbatli, E. C., Davis, S. J., Ito, A., \& Miake, N. (2017). Policy uncertainty in Japan (No. w23411). National Bureau of Economic Research. 
Arellano, M., \& Bover, O. (1995). Another look at the instrumental variable estimation of error-components models. Journal of Econometrics, 68(1), 29-51.Available at: https://doi.org/10.1016/0304-4076(94)01642-d.

Azam, M., Nawaz, M. A., \& Riaz, M. (2019). Does corruption and terrorism affect foreign direct investment inflows into Pakistan? Journal of Managerial Sciences, 13(2), 85-97.

Baker, S. R., Bloom, N., \& Davis, S. J. (2016). Measuring economic policy uncertainty. The Quarterly Journal of Economics, 131(4), 1593-1636.Available at: https://doi.org/10.1093/qje/qjw024.

Balcilar, M., Gupta, R., \& Segnon, M. (2016). The role of economic policy uncertainty in predicting US recessions: A mixed-frequency Markov-switching vector autoregressive approach. Economics: The Open-Access, Open-Assessment E-Journal, 10 (2016-27), 1-20.Available at: https://doi.org/10.5018/economics-ejournal.ja.2016-27.

Blundell, R., \& Bond, S. (1998). Initial conditions and moment restrictions in dynamic panel data models. Journal of Econometrics, 87(1), 115-143.Available at: https://doi.org/10.1016/s0304-4076(98)00009-8.

Brauer, J., \& Anderton, C. H. (2020). Conflict and peace economics: Retrospective and prospective reflections on concepts, theories, and data. Defence and Peace Economics, 31(40), 443-465.

Chen, J., Jiang, F., \& Tong, G. (2017). Economic policy uncertainty in China and stock market expected returns. Accounting E Finance, 57(5), 1265-1286.Available at: https://doi.org/10.1111/acfi.12338.

Chen, P.-F., Lee, C.-C., \& Zeng, J.-H. (2019). Economic policy uncertainty and firm investment: Evidence from the US market. Applied Economics, 51(31), 3423-3435.Available at: https://doi.org/10.1080/00036846.2019.1581909.

Cortez, R. M., \& Johnston, W. J. (2017). The future of B2B marketing theory: A historical and prospective analysis. Industrial Marketing Management, 66, 90-102.Available at: https://doi.org/10.1016/j.indmarman.2017.07.017.

Czech Republic Inflation Rate. (2020). Macrotrend.Com. Retrieved from: https://www.macrotrends.net/countries/CZE/czech-republic/inflation-rate-cpi.

Demir, E., \& Ersan, O. (2017). Economic policy uncertainty and cash holdings: Evidence from BRIC countries. Emerging Markets Reviere, 33, 189-200.Available at: https://doi.org/10.1016/j.ememar.2017.08.001.

Ghosh, S. (2019). Uncertainty, economic growth its impact on tourism, some country experiences. Asia Pacific Journal of Tourism Research, 24(1), 83-107.Available at: https://doi.org/10.1080/10941665.2018.1542324.

Handley, K., \& Limao, N. (2015). Trade and investment under policy uncertainty: Theory and firm evidence. American Economic Journal: Economic Policy, 7(4), 189-222.

Hu, Z., Kutan, A. M., \& Sun, P.-W. (2018). Is US economic policy uncertainty priced in China's A-shares market? Evidence from market, industry, and individual stocks. International Review of Financial Analysis, 57, 207-220.Available at: https://doi.org/10.1016/j.irfa.2018.03.015.

Huang, X.-L., Chen, G., \& Lee, E.-H. (2019). The moderating effect of internal control on performance of cross-border M\&A under the uncertainty of economic policy: Evidence from China. Journal of Korea Trade, 23(7), 128146.Available at: https://doi.org/10.35611/jkt.2019.23.7.128.

Iqbal, U., Gan, C., \& Nadeem, M. (2020). Economic policy uncertainty and firm performance. Applied Economics Letters, 27(10), 765-770.Available at: https://doi.org/10.1080/13504851.2019.1645272.

Jia, F., Huang, X., Xu, X., \& Sun, H. (2020). The effects of economic policy uncertainty on export: A gravity model approach. Prague Economic Papers.

Jindřichovská, I., Ugurlu, E., \& Thalassinos, E. I. (2020). Exploring the trend of Czech FDIs and their effect to institutional environment. International Journal of Economics \& Business Administration (IJEBA), 8(1), 94-108.

Jory, S. R., Khieu, H. D., Ngo, T. N., \& Phan, H. V. (2020). The influence of economic policy uncertainty on corporate trade credit and firm value. Journal of Corporate Finance, 64, 101671

Kang, W., de Gracia, F. P., \& Ratti, R. A. (2017). Oil price shocks, policy uncertainty, and stock returns of oil and gas corporations. Journal of International Money and Finance, 70, 344-359.Available at: https://doi.org/10.1016/j.jimonfin.2016.10.003.

Levin, A., Lin, C.-F., \& Chu, C.-S. J. (2002). Unit root tests in panel data: Asymptotic and finite-sample properties. Journal of Econometrics, 108(1), 1-24.Available at: https://doi.org/10.1016/s0304-4076(01)00098-7.

Perić, B. Š., \& Sorić, P. (2018). A note on the economic policy uncertainty index. Social Indicators Research, 137(2), 505526.Available at: https://doi.org/10.1007/s11205-017-1609-1.

Pesaran, M. H. (2004). General diagnostic tests for cross section dependence in panels. University of Cambridge, Cambridge Working Papers in Economics, 435.

Phan, D. H. B., Iyke, B. N., Sharma, S. S., \& Affandi, Y. (2020). Economic policy uncertainty and the financial stability-Is there a relation? Economic Modelling, 1-12.

Skrinjarić, T., \& Orlović, Z. (2020). Economic policy uncertainty and stock market spillovers: Case of selected CEE markets. Mathematics, 8(7), 1077.Available at: https://doi.org/10.3390/math8071077.

Synnott, M. (2019). The destruction of capital: A prospective theory of recovery within Marxian crisis literature: University of Sydney. (Master's Thesis, University of Sydney).

Tam, P. S. (2018). Global trade flows and economic policy uncertainty. Applied Economics, 50(34-35), 3718-3734.Available at: https://doi.org/10.1080/00036846.2018.1436151.

$\mathrm{Xu}$, Z. (2020). Economic policy uncertainty, cost of capital, and corporate innovation. Journal of Banking E Finance, 111, 105698.Available at: https://doi.org/10.1016/j.jbankfin.2019.105698.

Zeng, J., Zhong, T., \& He, F. (2020). Economic policy uncertainty and corporate inventory holdings: Evidence from China. Accounting \& Finance, 6O(2), 1727-1757.Available at: https://doi.org/10.1111/acfi.12511. 